\title{
The MBA Factor: A Study of Progression
}

\author{
Dr. Diane D. Galbraith \\ Associate Professor, School of Business \\ Slippery Rock University \\ Dr. Sunita Mondal \\ Assistant Professor, School of Business \\ Slippery Rock University
}

\begin{abstract}
Many students are flocking to business schools for more advanced degrees than in any other concentration. In what some call, a one to two-year hiatus, these students are trying to reverse the recent trend of a downwardly mobile generation with fewer opportunities and more accumulated debt. Master of Business Administration graduates are seeking a better future, upward mobility and satisfying jobs upon graduation. A 2015 Bloomberg study of the best business schools reveals that $88 \%$ are hired within 3 months of graduation, with a substantial jump of up to $81 \%$ in compensation before school. This study utilizes survey data to follow the graduates of a Mid-Atlantic University as their careers progress after graduation to determine whether there is a tangible return on their educational investment and an increase in their respective skill development. Results confirm the usefulness of the MBA degree in career progression.
\end{abstract}

KeyWords: Graduate studies; career outcomes; progression; educational investment

JEL Classification: A23

\section{INTRODUCTION}

In 2011-2012, there were 191,571 students who graduated from U.S. universities with advanced degrees in business, which accounts for $25.4 \%$ of all the Master's degrees conferred. The Master of Business Administration (MBA) is listed as one of the most successful degrees in the last century, due to the normal return on investment and the widespread acceptance by employers (Byrne, 2014). Students in the MBA programs often delay their enrollment in graduate school after completing their Bachelor's degree. They acquire work experience and most continue working full time while earning the MBA degree. Students enrolled in the MBA program face challenges of rigorous curriculum, financial resources, and managing to find the balance between full-time work and family obligations (U.S. Department of Education, 2011).

Nationally, MBA students acquire an average debt of $\$ 56,157$ (U.S. News, 2015). This study will analyze the returns and benefits to such educational investment utilizing a public Mid-Atlantic university data as a case example. In particular, this paper will review students' job placements following graduation, and change of position within current work place upon successful completion of the graduate program. The study aims to describe whether the employment opportunities and career options of the students are enhanced with a MBA degree and commensurate skill development. Research toward a better understanding of opportunity in 
postgraduate education is needed to measure the postgraduate academic success and employment opportunities.

\section{LITERATURE REVIEW}

The economy is changing and labor demand is far surpassing supply particularly for high -skill labor. McKinsey Global Institute (MGI) in a 2012 study predicts that the global labor force will reach 3.5 billion in 2020. This report lists the following challenges:

- 38 million to 40 million fewer workers with tertiary education (college or postgraduate degrees) than employers will need, or 13 percent of the demand for such workers

- 45 million too few workers with secondary education in developing economies, or 15 percent of the demand for such workers

- 90 million to 95 million more low-skill workers (those without college training in advanced economies or without even secondary education in developing economies) than employers will need, or 11 percent oversupply of such workers.

Richard Dobbs, one author of this report comments, "Unemployment for less skilled workers is currently running two to three times that of those skilled workers with university or postgraduate degrees. The demand for high-skilled workers defined as a college degree or higher is projected to be 166-168 million workers vs. the supply of 150 million. This will only intensify the global war for talented workers.

From a U.S. News and World Report article, (Bidwell, 2013), universities are unable to keep pace with available job openings. As a result, there will be a shortage of 5 million workers with essential training and education by 2020 in the U.S. Job growth is outpacing post-secondary and graduate rates. Regionally, the data is similar. In a 2016 study entitled, Inflection Point: Supply, Demand and the Future of Work in the Pittsburgh Region, from the Allegheny Conference on Community Development, the report projects a shortage of 80,000 workers by 2025 due to massive Baby Boomer retirements also termed the, silver tsunami, and insufficient post-graduate rates to fill the gaps in the workforce. In Business and Finance, $89 \%$ of the new positions require at least a Bachelor's degree (p. 26). These occupations are growing at a rate of $5 \%$, but there is not enough local talent in the area to fill these positions. The gap is more pronounced at the bachelor's and graduate level, where there are 4,000 annual openings being met by only 3,000 new graduates (p.26). As noted, the demand is much higher than the available and qualified workforce.

A partial explanation of the shortage of supply of skilled labor could be attributed to the higher cost and increased debt burden (illustrated in figure 1 below). The increasing costs of higher education and the resulting mount of debt discourages pursue of advanced degrees. Eventually this leads to a shortage of skilled workers and explains the gap in labor supply-demand. 
Figure 1: Supply and Demand of Business and Finance workers from

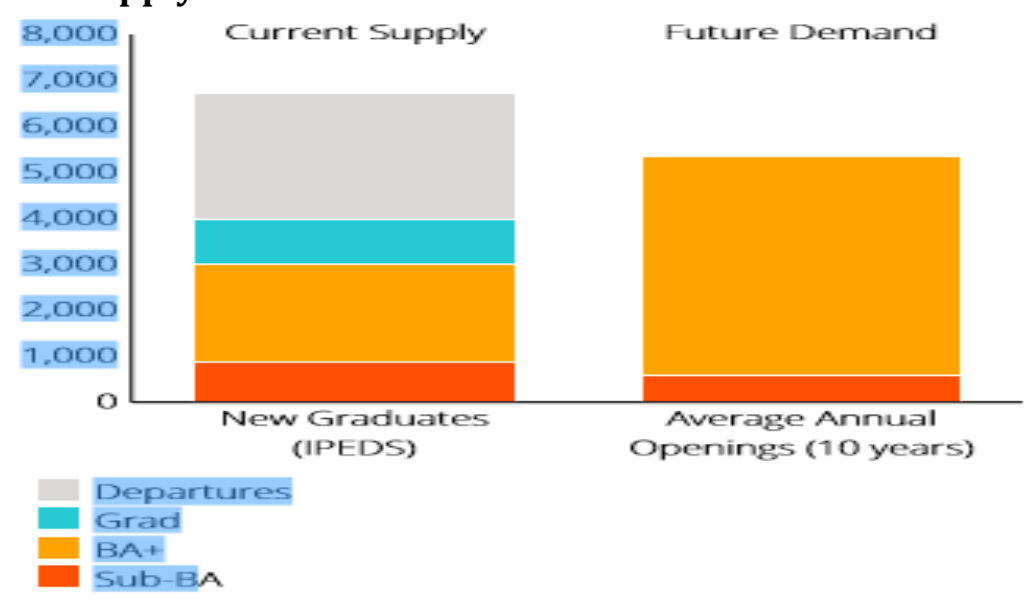

Source: Alleghenyconference.org., May, 2016

MBA programs can help to reduce this imbalance by providing curricula for students that is directly aligned with business needs and skill sets. Although, the MBA degree continues to grow in popularity and value, it does not seem to be a competitive differentiator anymore. Rather this degree is viewed as the next natural credential in one's career. Just as undergraduate degrees are as ubiquitous as high school diplomas were in the past, the MBA now serves as a baseline for career progression. Byrne, (2014) reveals that advanced degrees today are as common as bachelor's degrees were in the 1960s, according to The Department of Education. More than 16 million people in the U.S., roughly $8 \%$ of the country's population, have a master's degree, a $43 \%$ increase since 2002.

Graduate degrees have also proven to have a positive return on investment. A recent study by the Urban Institute in (Byrne, 2014) depicted that the average earnings for fulltime workers ages 35-44 with master's degrees in 2002 were 8\% higher than those for similar workers in the same demographic group, whose highest degree was a bachelor's. The difference ballooned to $21 \%$, just 10 years later.

Table 1 from the Employment Bureau of Labor Statistics and the Allegheny Conference, (2016) report, indicates a relatively healthy growth rate in the region.

Most of the Business and Finance occupations illustrated have a positive future outlook. Noteworthy are the median salaries and the requirement of an advanced degree including accountants that need at least a Bachelor's degree for employment.

The need for higher education is clear with the impending skills shortage, but the next challenge is the debt associated with advanced degrees that has tripled in the last decade The information from the Federal Reserve (figure 2 below) depicts that school loan debt is higher than motor vehicle debt. 


\section{Table 1: Business and Finance Occupational Summary}

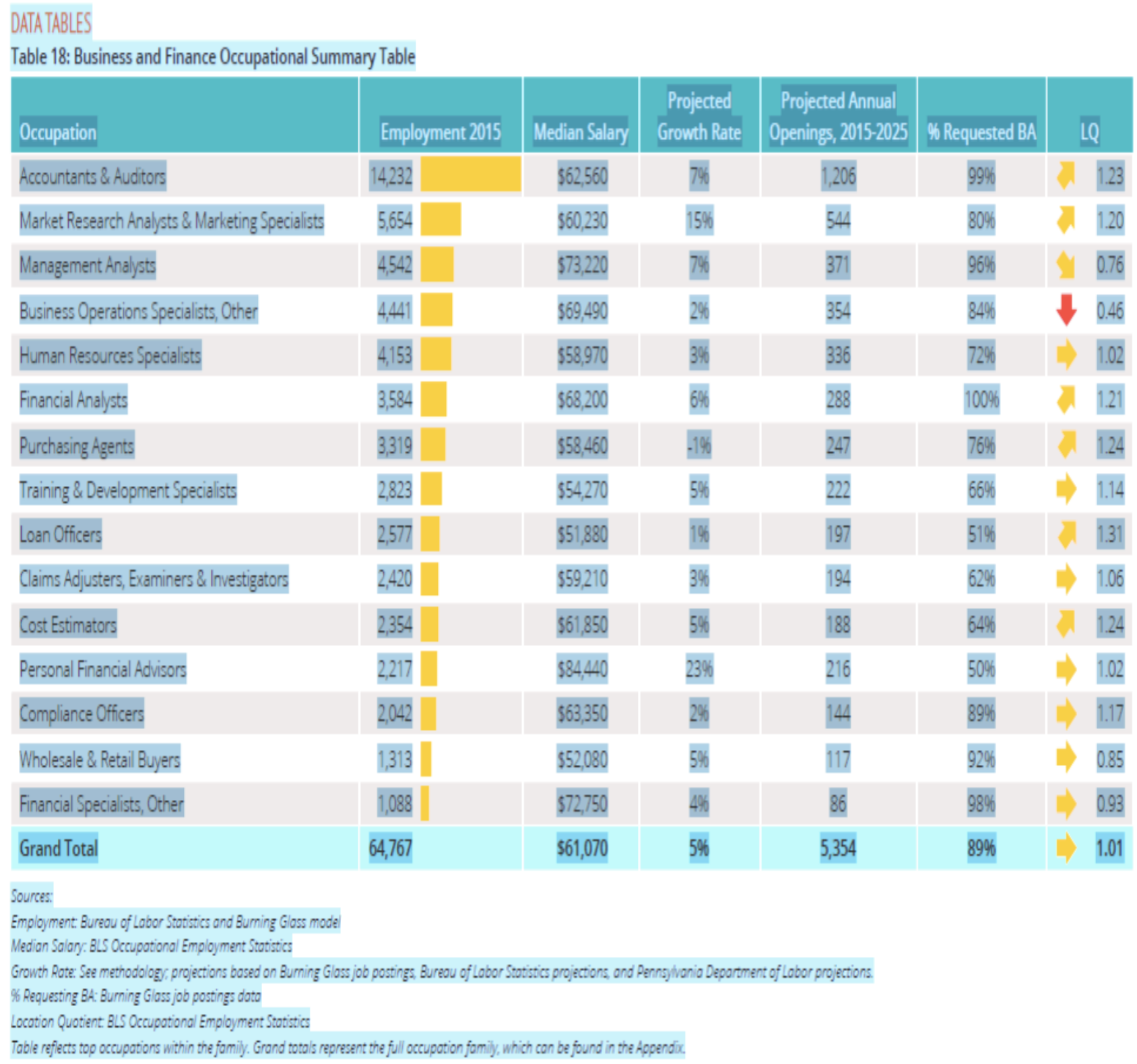


Figure 2: Student Loan Debt

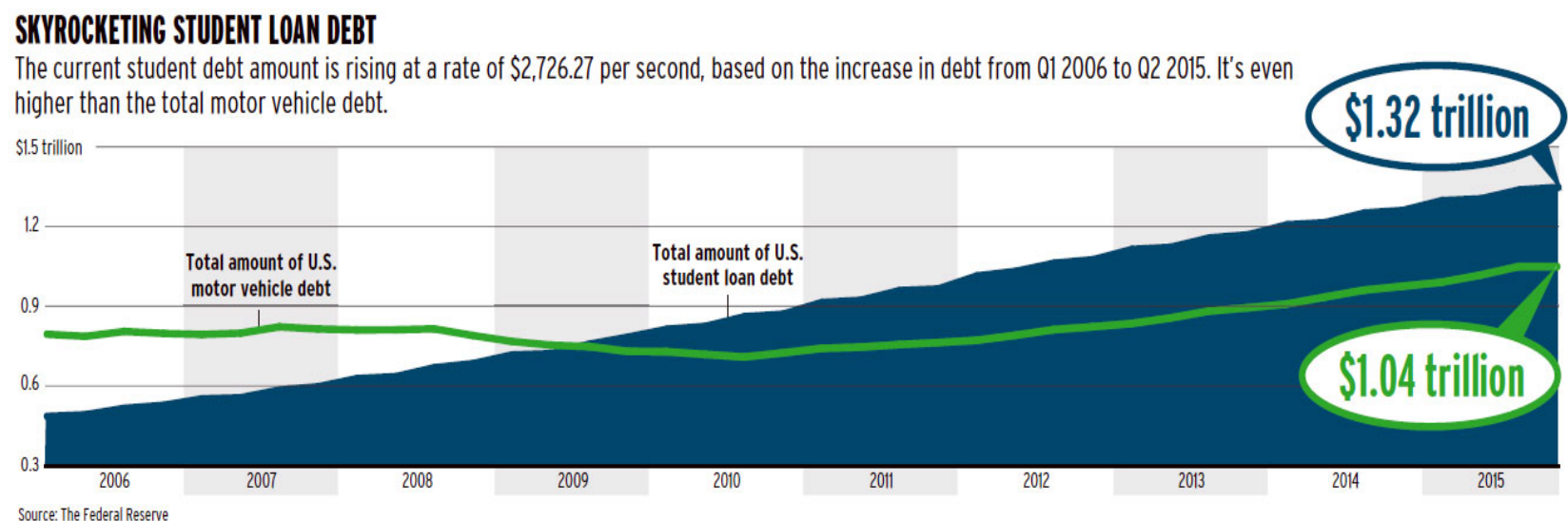

(Source: The Federal Reserve, 2016)

According to a College InSight 2014 report, 69\% of university students, from both private and public institutions, had student loan debt, with an average of $\$ 28,950$ per borrower. Over the last decade-from 2004 to 2014 - the share of graduates with debt rose modestly (from $65 \%$ to $69 \%$ ) while average debt at graduation rose at more than twice the rate of inflation. In Pennsylvania, the state average is $\$ 33,264$ for student debt and the Mid-Atlantic university in our case study in 2014 was $\$ 30,458$, and $86 \%$ of the graduates ended up with debt.

In addition, wages for college graduates have not kept pace with inflation after the Great Recession as reported from the Economic Policy Institue (2016). The research concluded that wages were no higher than in the year, 2000. Real average hourly wages of young workers categorized by education and gender were relatively stagnant. The data used college graduates, ages 21-24 who did not have advanced degrees and were not enrolled in further schooling. There are bright spots, though such as in the consulting field. Many MBA graduates look to consulting companies as a career choice upon graduation. Managementconsulted.com (2016) states that since banking salaries have increased (up to $25 \%$ at the MBA level), consulting firms needed to remain competitive by raising their base pay for MBAs to $\$ 140,000+$.

Although, this may look insurmountable in some cases, graduates are adapting by scaling back on purchases like home ownership and other consumer spending with the reality that many will make higher-than-average salaries. In addition, companies like PricewaterhouseCoopers, the Big Four accounting and consulting firm are offering a student loan reduction benefit whereby they will help the employee pay down up to $\$ 7200$ of loan payments. PwC estimates that 45 percent of its U.S. workforce of 46,000 is eligible for the perk (Strahler, 2016). Naxis Global Asset Management, Fidelity Investments and Chegg educational services also offer loan reduction benefits.

Equipped with this knowledge, what is the allure for students to pursue a MBA degree? The target market according to Steve James, an Executive Director of a university MBA program in South Florida, are 3 main groups of those seeking MBA degrees:

1. Those in their early to mid-30s who have enjoyed career success, and want to move ahead and set themselves apart from their peers. This group tends to do part-time or online MBA programs.

2. Those in their mid-20s who want to strengthen their academic credentials and focus on a specialty before entering the job market. This group tends to study full time.

3. Those that want or need to switch careers. They are more common during bad economic times. They study full time. "They're looking for a bridge to another career," says James. 
In a 2016 study by Development Dimensions International (DDI), analyzing 15,000 people in 18 countries across 300 organization represeting 20 different industries, business education fared relatively well. Profits matter for sustainable businesses. The study reviewed the competencies that fueled organizational growth and profit with specific emphasis on organizations that invested in growing skilled leaders as compared to their competitors. Figure 3 below illustrates revenue and important competencies:

Figure 3: Leadership Competencies Drive Organizational Growth and Profit, and Top and Bottom Ranked Educational Degrees

Leadership Competencies Drive Organizational Growth and Profit

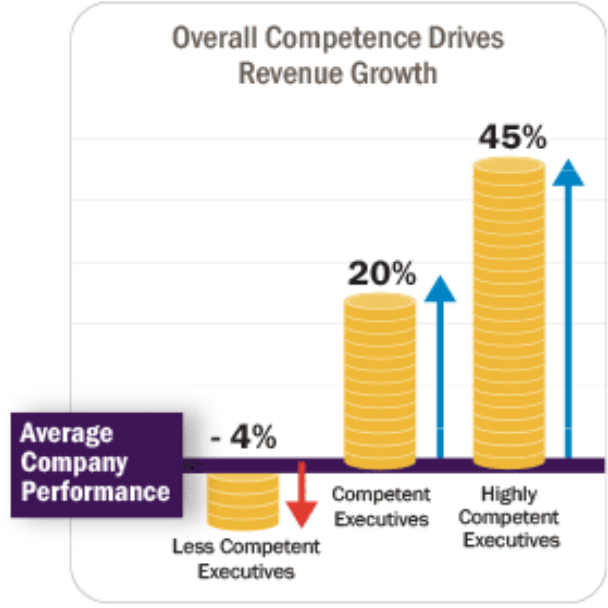

Specific Business and Leadership Competencies Drive Profit

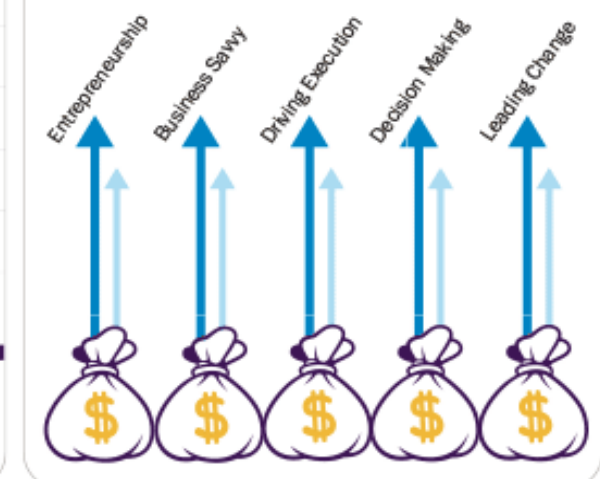

CDevelopment Dimensions Intemational, Inc., 2015. All rights reserved.

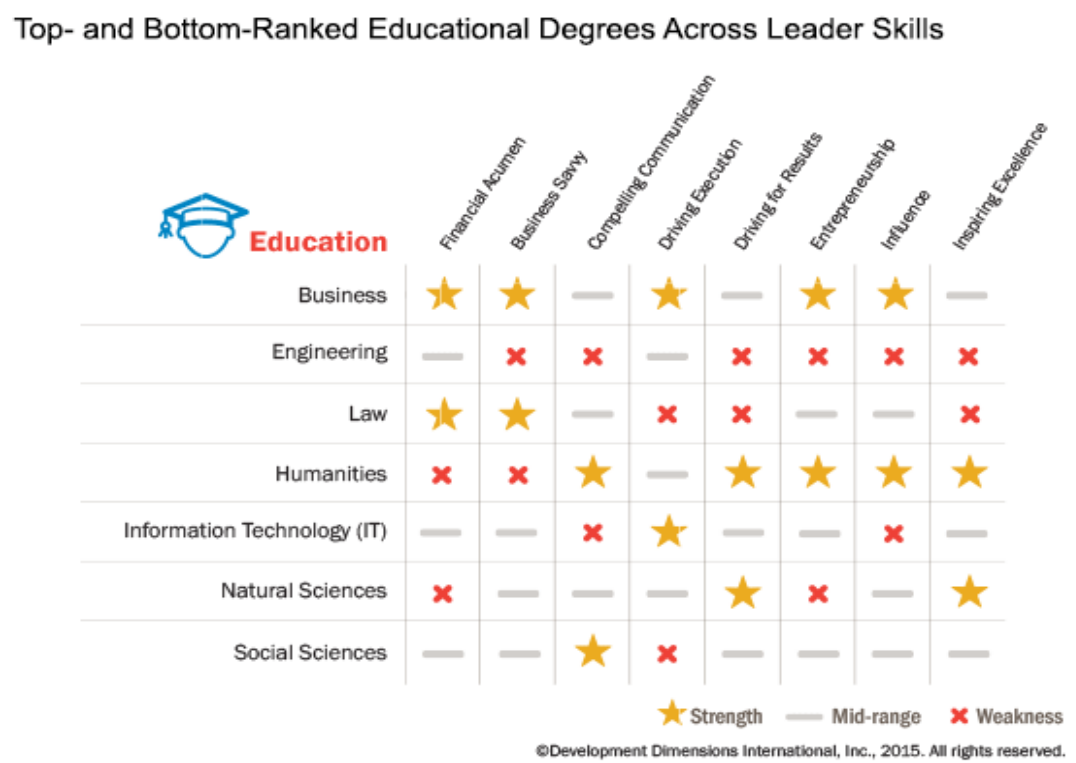

There are some skeptics though. MBA's have also been much maligned recently for a number of reasons. Navaro (2008), reviewed curricula from top-ranked business schools in America and concluded that there is a deficiency in soft skills, globalization, information technology and corporate social responsibility. Cross-cultural training, culturally-specific soft skills and international curricula are essential for successful careers abroad. MBA programs will need to continue to partner with the business community to ensure that the proper skills are identified and honed in preparation for the workforce to fill the skills gaps that mutually benefit the organizations and the individuals.

Finally, in a post-graduate study, interviewing MBA graduates a decade after their graduation, Wachter, (2014), uncovered a very diverse population. One recurring theme was not a 
unilateral pursuit of wealth or status, but rather a quest for a career with meaning and balance. The narratives pointed toward an alignment between the person and the position, with twists and turns in the journey, lessons learned and creation of each person's unique story. Other benefits of MBA's include lower unemployment rates, a better work/life balance, more career agility and social mobility.

\section{METHODOLOGY}

This is a descriptive study to track the progress of recent MBA graduates from a state, public university. The study aims to identify the career progression of individuals who have completed the MBA program. It analyzes whether a graduate degree enables individuals to advance in their respective careers and/or climb up the corporate ladder. A discussion of qualitative variables was undertaken, with the aim of accessing information regarding factors that contribute to a measure of success in the labor market, which could be subjective to personal goals and aspirations. Towards that goal, a survey was prepared which addresses such questions as:

"Do you believe your MBA degree has contributed towards your career progression"? "Do you think you grew professionally and personally as a result of the MBA program"? The survey was administered through Survey Monkey, and reached out to all recent MBA graduates from a mid-Atlantic university. The survey results indicate the perceived benefits that the recent graduates attribute to the MBA program, with respect to the cost borne.

\section{DATA AND RESULTS}

This study uses a mid-Atlantic university as a case example. This public university is a member of a State System of Higher Education, which enrolls a diverse student body, with a total enrollment of approximately 8,200 students. The university offers a full range of traditional academic programs including Bachelors', Masters' and some Doctorate degrees. In many ways, this sample study reflects the institutional characteristics of a representative major public university in the country. The study utilized individual survey data, administered by the authors, of recent MBA graduates. The data set consists of individuals who responded to the survey on questions related to their career progression following the completion of the MBA degree. The completion years ranged from 2014-2016, with one student expecting to graduate in 2017. Figure 4 below depicts the degree completion year in percentage terms. A majority of the students graduated in 2015 and 2016. In addition, a vast majority (88 percent) of students were registered as full-time towards the completion of the MBA degree. About 75 percent of the survey respondents are male. The survey respondents belong to a variety of industries ranging from finance, real estate, healthcare to education, information technology and athletics.

Figure 4: Completion Year of MBA Degree (percentage of students)

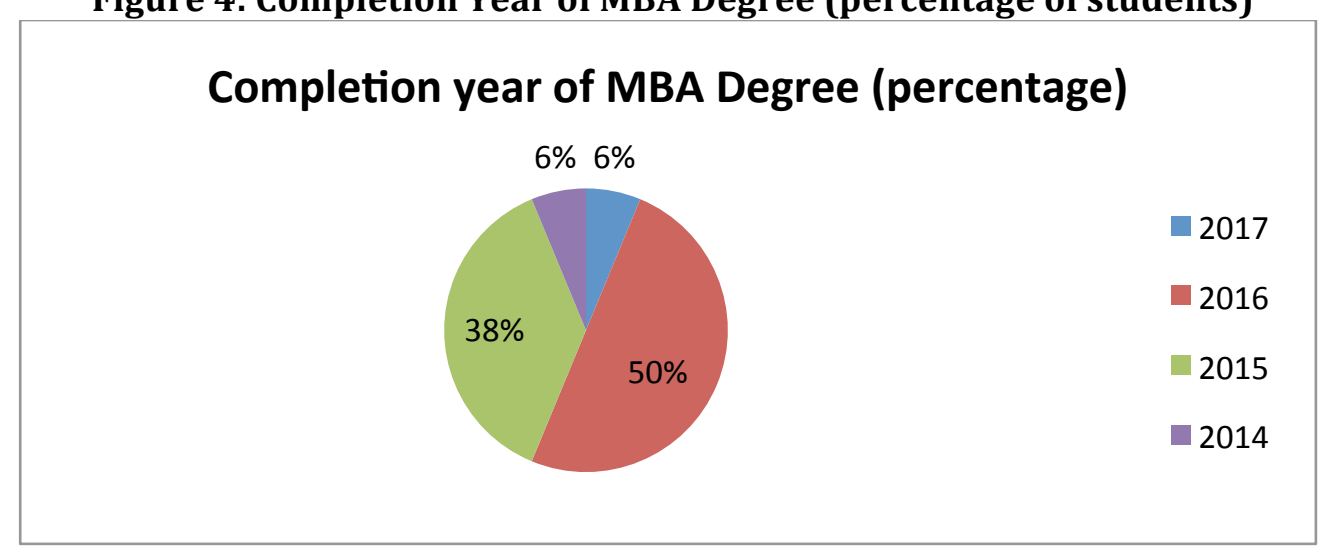


In further analyzing the survey responses, the data indicate about 57 percent of the recent graduates remained within the same organization or company after completion of the MBA degree. Amongst those who remained, about 67 percent were in the same position as before the degree. The remaining 33 percent did remain with the same company; however, there was a change in their position, a progression within the company, following the completion of the MBA program.

Around 44 percent did move from their original organization, during their schooling, and amongst those who moved, a majority of 83 percent obtained a promotion. The remaining 17 percent did change companies, but this did not reflect a work promotion. Table 2 reports the results.

Table 2: Career Change with MBA Degree

\begin{tabular}{|l|c|c|}
\hline & $\begin{array}{c}\text { Yes } \\
\text { (percentage) }\end{array}$ & $\begin{array}{c}\text { No } \\
\text { (percentage) }\end{array}$ \\
\hline Same Organization/Company & 56 & 44 \\
\hline If Yes, same position & 67 & 33 \\
\hline $\begin{array}{l}\text { If No, changed companies for a } \\
\text { promotion }\end{array}$ & 83 & 17 \\
\hline
\end{tabular}

With regards to the perception of recent graduates on the value-added of the MBA degree, the responses are reported in Figure 5 below. In answer to the question of whether the MBA degree has contributed to the career progression, 73 percent of the respondents agreed, and 4 percent disagreed. The remaining 20 percent respondents did not directly address the question, however, provided positive feedback on the degree through comments which include, "I believe that it has given me the upper hand in my career progression over other just as qualified candidates because of having that MBA".

In response to the question of whether there has been a professional growth as a result of the MBA degree, 88 percent of respondents agreed to such growth, and the remaining 12 percent provided written comments attributing their professional success to the MBA degree.

Finally, in response to the question on whether the MBA degree added value to their career progression, the positive response was 100 percent, with all of the survey respondents agreeing to the positive influence of an MBA degree on their career path progression. 
Figure 5: Valuation of an MBA Degree

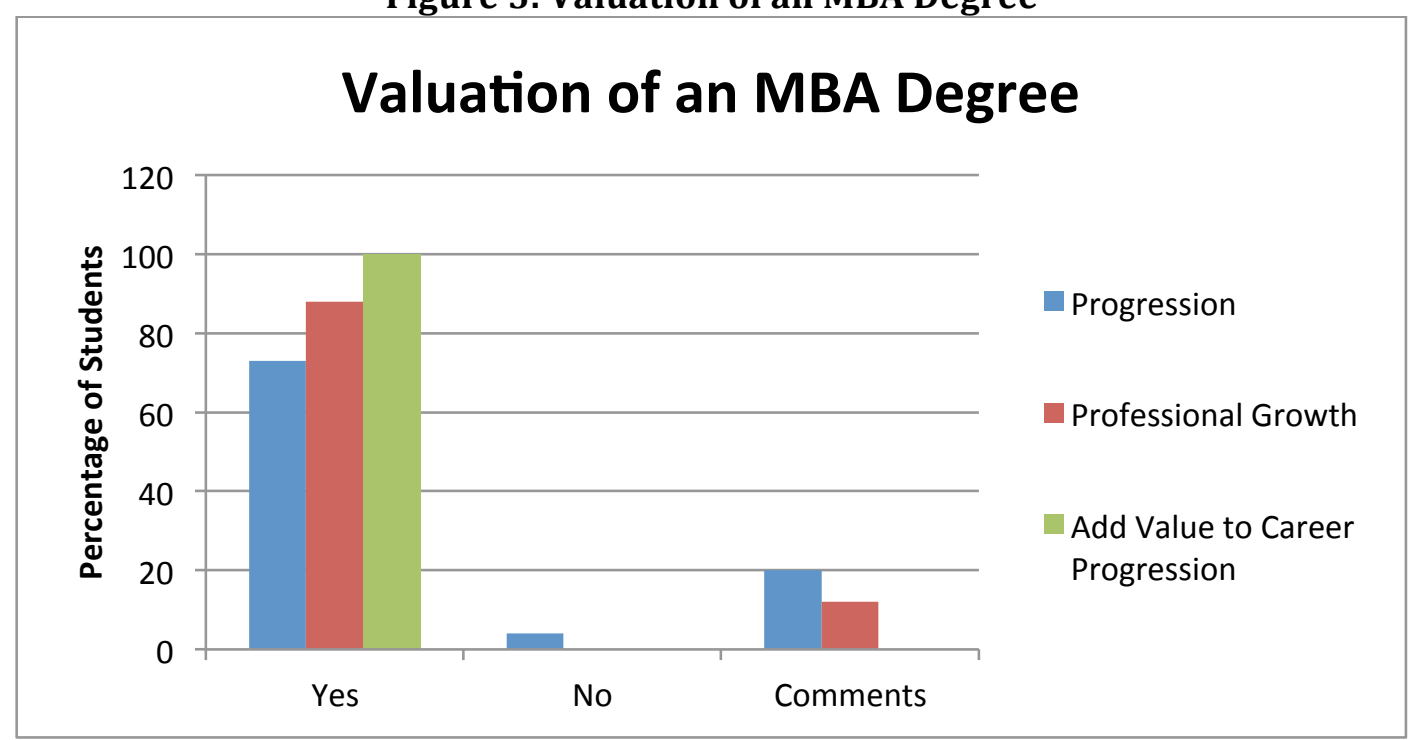

\section{FURTHER DATA ANALYSIS}

In order to further strengthen our confirmation of the positive impact of an MBA degree by our students, we included an additional dataset in our analysis. This data is based on survey responses from current MBA students in the program, alumni MBA students, and the MBA faculty and staff. There were 12 current students, 17 alumni students and 16 faculty and staff members who responded to the survey. The results from the survey in response to the question, "Overall, the MBA program is an effective program" is reported in Figure 6 below. The results indicate that a majority of current and alumni students confirm the effectiveness of the program. Among the reasons provided by the students for answering no to the effectiveness question, include inadequate time for the rigorous program due to their full-time work responsibilities, and poor placements on the completion of the program.

Figure 6: Effectiveness of the MBA Program

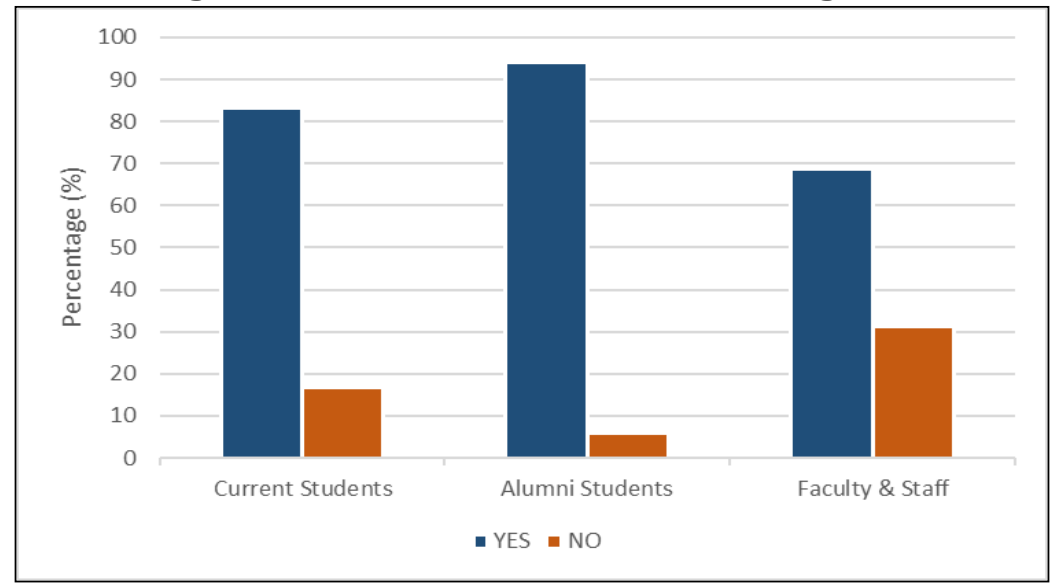

Out of the current and alumni students being asked the question, "would you recommend the program to others", a majority of students responded positively, as reported in Figure 7 below. 
Figure 7: Recommend the MBA Prgoam to others

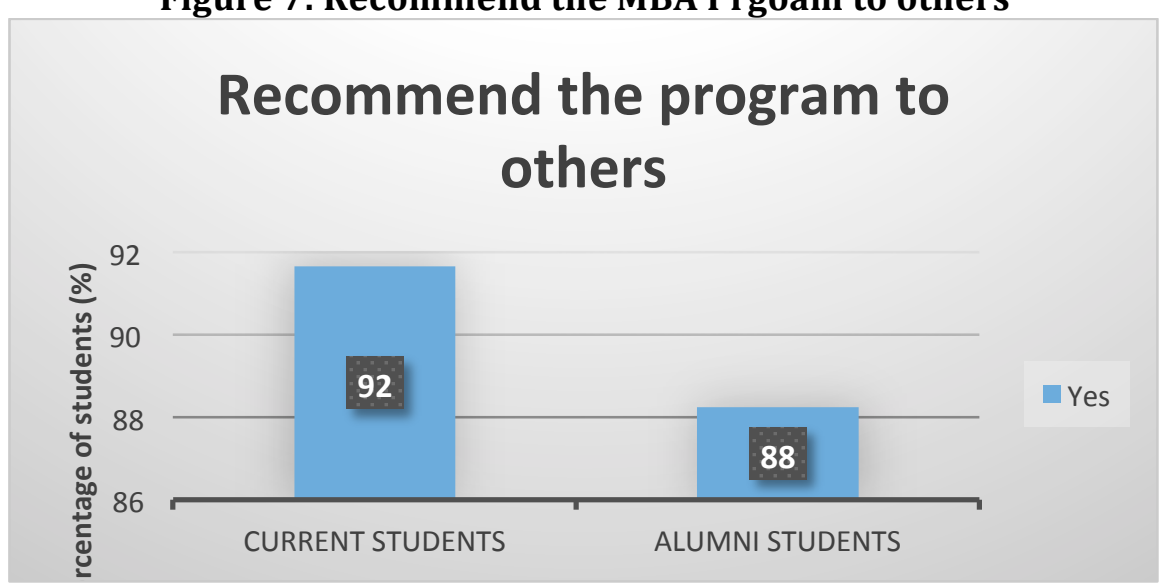

In response to the survey question regarding the preferred format for the course, about $100 \%$ of the current students liked the blended format, while $88 \%$ of the alumni students chose the blended format, with the rest, $12 \%$ of alumni students preferring a fully online program. The results are reported in table 3 below.

Table 3: Preferred format for MBA course

\begin{tabular}{|l|c|c|}
\hline & $\begin{array}{c}\text { Blended } \\
\text { (\%) }\end{array}$ & $\begin{array}{c}\text { Fully Online } \\
\text { (\%) }\end{array}$ \\
\hline Current Students & 92 & 8 \\
\hline Alumni Students & 88 & 12 \\
\hline
\end{tabular}

\section{CONCLUSION AND DISCUSSION}

The survey response data confirms the positive impact of an MBA degree as perceived by the recent graduates of a mid-size public state university. Most of the graduates believe that an MBA degree has enhanced their skills and growth toward their career goals and is helping them in terms of better opportunities and positions, both within and across organizations and industries.

There are a myriad of MBA programs in the US for applicants to choose from. Many have speculated that there are too many and even a glut, resulting in the overall value of these programs being diluted. The benefits from a higher degree, however, are based on supply and demand, educated, skilled talent (supply) and employer needs (demand). The graduates from our study make more than the average Bachelor's degree, confirming the worth of the MBA program in financial terms, notwithstanding the learning process and intrinsic value as well. In analyzing the results, the point that these are very recent graduates should be kept in mind. The full potential of the MBA degree might take some time to be realized.

Authors believe the results would provide beneficial information to the university regarding the outcomes of graduate MBA program and the likelihood of successful completion rates for these students. In addition, extending this study may also prove valuable. The results will help academic institutions, administrators and policymakers to better understand the different pathways to graduate school success. Also collaboration with the Career Services offices at respective universities should be able to capitalize on this type of research to prioritize their limited resources. 
This study supports earlier research results regarding the reasons that individuals chose MBA programs to both strengthen their academic credentials and/or would like to change jobs or careers. Although, the debt burden continues to rise, this sample seems to belie the trend of higher debt with little return. These recent graduates are already realizing substantive economic gains, based on their choice to further their education.

\section{References}

Becker, G. (1967). Human capital and the personal distribution of income: An analytical approach. Ann Arbor: University of Michigan Press.

Bidwell, A. (2013). Report: Economy will Face Shortage of 5 Million Workers in 2020. Retrieved May 16, 2016 from: http://www.usnews.com/news/articles/2013/07/08/report-economy-will-face-shortage-of-5-millionworkers-in-2020

Bureau of Labor Statistics (March 2014). Current Population Survey, U.S. Department of Labor, U.S. Bureau of Labor Statistics. Earnings and unemployment rates by educational attainment.

Byrne, J. A. (May 31, 2014) Why the MBA has become the most popular master's degree in the U.S. Retrieved May 17, 2016 from: www.forbes.com

College InSight. (2014). College access and Success. Retrieved May, 19, 2016 from: http://ticas.org/posd/mapstate-data\# overlay=posd/state_data/2015/pa

Dobbs, R., Madgaykar, A., Barton, D., Labaye, E., Manyika, J., Roxburgh, C., Lund, S., Madhay, S. (June, 2012). The world at work: Jobs, pay, and skills for 3.5 billion people.

McKinsey Global Institute.

Dougherty, K. J. (1992). Community colleges and baccalaureate degree attainment. The Journal of Higher Education, 63, 188-214.

Eide, E.R., and Hilmer, M. J. (2016). Do elite colleges lead to higher salaries? Only for some professions. Retrieved February 1, 2016 from: http://www.wsj.com/articles/do-elite-colleges-lead-to-higher-salaries-only-for-someprofessions-1454295674

Ganderton, P. T., \& Santos, R. (1995). Hispanic college attendance and completion: Evidence from the High School and Beyond Surveys. Economics of Education Review, 14(1), 35-46.

High-resolution leadership: A synthesis of 15,000 assessments into how leaders shape the business landscape (2016). Retrieved, May 16, 2016 from: www.ddiworld.com/hirezleadership

Hilmer, Michael J. (1999). Does the return to university quality differ for transfer students and direct attendees? Economics of Education Review, 19(1), 47-61.

Hilmer, Michael J. (2002). Human capital attainment, university quality, and entry-level wages for college transfer students. The Southern Economic Journal, 69(2), 457-469.

Kroeger, T., Cooke, T., and Gould, E. (April, 2016). The Class of 2016: The labor market is still far from ideal for young graduates' report. Economic Policy Institute.

Laband, David, and Piette, Michael. (1995). Does who teaches principles of economics matter? American Economic Review, 85(2), 335-338.

Lewis, Darrell R., Wentworth, Donald R., and Orvis, Charles C. (1973). Economics in junior colleges: Terminal or transfer? Journal of Economic Education, 4(2), 100-110.

Management Consulting Salaries - Undergraduate, MBA, Interns and More (2016). Retrieved May 16, 2016 from: https://managementconsulted.com/consulting-jobs/2016-management-consulting-salaries-undergraduate-mbainterns/\#

Navarro, P. (2008). The MBA core curricula of top-ranked U.S. business schools: A study in failure? Academy of Management Learning \& Education. 7(1), 108-123.

N/A. Does an MBA guarantee success? Retrieved May 9, 2016 from: https://secure.gacollege411.org/Home/Article.aspx?level...articleId 
N/A. (2016). Inflection Point: Supply, Demand and the Future of Work in the Pittsburgh Region: A forward look at the coming transformation of work across the Pittsburgh region and its implications for employers, educators and workforce talent. Burning Glass Technologies and The Council for Adult and Experiential Learning with: Allegheny Conference on Community Development, AlleghenyConference. org.

Rodkin, J. and Levy, F. (2016). Best business schools 2015. Retrieved February 13, 2016 from:http://www.bloomberg.com/features/2015-best-business-schools/

Snider, S. (July 28, 2015). 10 MBA Programs That Stick Grads with the Most Debt. US News.

Strahler, S. R. (March, 2016). The bigger gut-punch from college debt. Retrieved May 16, 2016 from: http://www.chicagobusiness.com.

Taylor, P. (2016). The kids are all left. Time, pp. 34-41. U.S. Department of Education (July 8, 2011). NCES 2011174. Stats in Brief: Graduate and First-Professional Students: 2007-08.

Wachter, S. (2014). Is there life after an MBA? Retrieved May 17, 2016 from: http://onforb.es/14JjlYY 